\title{
Glutathione Synthetase of Aspergillus niger: Structural Properties of the Enzyme in Prokaryotes and Eukaryotes
}

\author{
Kousaku Murata ${ }^{\dagger}$ Akira Kimura and Norio Yajima* \\ Research Institute for Food Science, Kyoto University, \\ Uji, Kyoto 611, Japan \\ * Asama Kasei Co., Ltd., Nihonbashi, Chuo-ku, \\ Tokyo 103, Japan
}

Received December 5, 1988

\begin{abstract}
Glutathione synthetase isolated from a mold, Aspergillus niger, had a molecular weight of 110,000 and consisted of two apparently identical subunits, each with a molecular weight of 55,000 . The enzyme was most active at $\mathrm{pH} \mathrm{8.5}$. It specifically utilized glycine and $\mathrm{ATP}$, and required $\mathrm{Mg}^{2+}$ or $\mathrm{Mn}^{2+}$ for its catalytic function. A comparison of glutathione synthetases from various sources indicated that the enzyme of eukaryotes (mammals, molds and yeasts) differ from those of prokaryotes (Escherichia coli $B$ and Proteus mirabilis) in molecular structure, although the enzymes from both types of organisms contain an active site thiol and catalyze the same reaction.
\end{abstract}

Glutathione synthetase [EC 6.3.2.3] is the second enzyme in the glutathione synthetic pathway and catalyzes the condensation of $\gamma$ L-glutamyl-L-cysteine with glycine in the presence of adenosine 5'-triphosphate (ATP). Glutathione synthetase has been studied, from mammalian sources (pigeon liver, ${ }^{1,2)}$ human and bovine erythrocytes ${ }^{3,4)}$ and cilliary epithelium $^{5)}$ ), higher plants (wheat germ $^{6}$ ), yeast (Saccharomyces cerevisiae $\left.{ }^{7,8}\right)$ and bacteria (Escherichia coli, ${ }^{9)}$ Escherichia coli $B^{10)}$ and Proteus mirabilis ${ }^{11)}$ ), and its physical properties have been well documented. The most highly purified glutathione synthetase was obtained from rat kidney. ${ }^{12)}$ It has a molecular weight of $118,000 \pm 4,000$ and is composed of two identical subunits. On the other hand, the enzyme from $E$. coli $B$ has a molecular weight of 140,000 and is cleaved into four identical subunits. ${ }^{10)}$ A molecular weight of 147,000 has been reported for the Proteus mirabilis enzyme, but its molecular structure is not yet clear. ${ }^{11)}$ However, there is a lack of information regarding the molecular structure of glutathione synthetases from eukaryotic microbial cells, except for the yeast enzyme, of which the molecular weight has been shown to be $123,000 .^{13)}$ We therefore present the physical properties of glutathione synthetase from a mold, Aspergillus niger, and compare the properties of the eukaryote and prokaryote enzymes.

\section{Materials and Methods}

Chemicals. Glutathione reductase and $\gamma$-L-glutamyl-Lcysteine were purchased from Nakarai Chemical Co., Ltd., Kyoto, Japan.

Assay for glutathione synthetase. Glutathione synthetase was assayed in a $1.0 \mathrm{ml}$ reaction mixture containing $15 \mathrm{~mm}$ $\gamma$-L-glutamyl-L-cysteine, $10 \mathrm{~mm}$ glycine, $10 \mathrm{~mm}$ ATP, $10 \mathrm{mM} \mathrm{MgCl} \mathrm{Mg}_{2}$ and $50 \mathrm{~mm}$ Tris- $\mathrm{HCl}$ buffer ( $\mathrm{pH} 7.5$ ) at $25^{\circ} \mathrm{C}$. The reaction was initiated by adding the enzyme and terminated by immersing the test tube in a boiling water bath for $3 \mathrm{~min}$. Glutathione and/or inorganic phosphate formed in the reaction mixture were determined by the method of Tietze ${ }^{14)}$ and Fiske and Subbarow, ${ }^{15)}$ respectively. Activity was expressed as $\mu \mathrm{mol}$ of glutathione or inorganic phosphate formed per hr per mg of protein, which was determined by the method of Lowry et al. ${ }^{16)}$

Purification of glutathione synthetase

1) Preparation of cell extracts. Aspergillus niger ATCC 9642 was cultured in a nutrient medium $(2.0 \%$ malt

\footnotetext{
$\dagger$ To whom correspondence should be addressed.
} 
extract, $0.1 \%$ peptone, $2.0 \%$ glucose, $0.02 \%$ yeast extract, tap water) at $30^{\circ} \mathrm{C}$ with reciprocation for $48 \mathrm{hr}$. The cells (122 g wet wt.) from $9 \mathrm{l}$ of culture were harvested through cheesecloth, resuspended in $100 \mathrm{ml}$ of $10 \mathrm{~mm}$ Tris $-\mathrm{HCl}$ buffer ( $\mathrm{pH} 7.5$ ) and then homogenized in a Dyno-Mill with the aid of glass beads for $5 \mathrm{~min}$ at $0^{\circ} \mathrm{C}$. The homogenate was centrifuged at $25,000 \times g$ for $20 \mathrm{~min}$ and the resultant supernatant was used for purification of the enzyme.

2) Ammonium sulfate fractionation. To the clear supernatant $(4,410 \mathrm{mg}$ protein, $500 \mathrm{ml}), 113 \mathrm{~g}$ of powdered ammonium sulfate was added, followed by stirring for $30 \mathrm{~min}$ at $0^{\circ} \mathrm{C}$. The precipitate was separated by centrifugation as above. To the supernatant, another $64 \mathrm{~g}$ of ammonium sulfate was added, followed by stirring for $30 \mathrm{~min}$ at $0^{\circ} \mathrm{C}$ and then centrifugation as above. The precipitate was dissolved in $40 \mathrm{ml}$ of $10 \mathrm{~mm} \mathrm{Tris-HCl}$ buffer $(\mathrm{pH} \mathrm{7.5)}$ and then dialyzed against the same buffer at $4 \mathrm{C}$ overnight.

3) Ion-exchange chromatography. The dialysate (1,750 mg protein, $55 \mathrm{ml})$ was applied to a DEAE-cellulose column $(6.0 \times 50 \mathrm{~cm})$ equilibrated with $10 \mathrm{~mm}$ Tris $\mathrm{HCl}$ buffer $(\mathrm{pH} 7.5)$. The proteins were eluted with a linear gradient of $\mathrm{KCl}(0 \sim 0.9 \mathrm{M}$; volume, $9,000 \mathrm{ml})$ in the same buffer at the flow rate of $48 \mathrm{ml} / \mathrm{hr}$. Fractions of $3.2 \mathrm{ml}$ were collected, and the active fractions, which were eluted at $0.25 \mathrm{M} \mathrm{KCl}$, were combined and then concentrated by ultrafiltration using an Amicon PM10 membrane to about $5 \mathrm{ml}$.

4) Ist exclusion chromatography. The concentrate (195 $\mathrm{mg}$ protein, $5 \mathrm{ml}$ ) was applied to a Sephadex G-150 column $(2 \times 90 \mathrm{~cm})$ equilibrated with $10 \mathrm{~mm}$ Tris- $\mathrm{HCl}$ buffer ( $\mathrm{pH} 7.5$ ) and then the proteins were eluted with the same buffer. The flow rate was $32 \mathrm{ml} / \mathrm{hr}$ and fractions of $3.2 \mathrm{ml}$ were collected. The active fractions (Nos. $39 \sim 49$ ) were pooled and then concentrated to $3 \mathrm{ml}$ as above.

5) Ion-exchange/exclusion chromatography. The concentrate $(52.8 \mathrm{mg}$ protein, $3 \mathrm{ml})$ was applied to a DEAESepharose CL-6B column $(1.5 \times 95 \mathrm{~cm})$ equilibrated with $10 \mathrm{~mm}$ Tris $-\mathrm{HCl}$ buffer $(\mathrm{pH} 7.5)$. The proteins were eluted with a linear gradient of $\mathrm{KCl}(0 \sim 0.6 \mathrm{M}$; volume, $350 \mathrm{ml})$ at the flow rate of $53 \mathrm{ml} / \mathrm{hr}$. Fractions of $3.5 \mathrm{ml}$ were collected, and the active fractions, which were eluted at about $0.26 \mathrm{M} \mathrm{KCl}$, were combined and then concentrated to $3 \mathrm{ml}$ as above.

6) 2nd exclusion chromatography. The concentrate (6.72 $\mathrm{mg}$ protein, $3 \mathrm{ml}$ ) was applied to a Sephadex $\mathrm{G}-150$ column $(1.5 \times 90 \mathrm{~cm})$ equilibrated with $10 \mathrm{~mm}$ Tris- $\mathrm{HCl}$ buffer ( $\mathrm{pH} 7.5$ ) and then the enzyme was eluted with the same buffer at the flow rate of $18 \mathrm{ml} / \mathrm{hr}$. Fractions of $1.5 \mathrm{ml}$ were collected and the active fractions (Nos. $32 \sim 37$ ) were pooled.

7) Hydrophobic chromatography. The enzyme solution $(2.71 \mathrm{mg}$ protein, $9 \mathrm{ml})$ was saturated with ammonium sulfate $(30 \%)$ and then applied to a Butyl-Toyopearl $650 \mathrm{M}$ column $(1.0 \times 3.0 \mathrm{~cm})$ equilibrated with $10 \mathrm{~mm}$ Tris $-\mathrm{HCl}$ buffer ( $\mathrm{pH} 7.5)$ saturated with ammonium sulfate $(30 \%)$. The enzyme was eluted with a linear gradient of ammonium sulfate $(30 \sim 0 \%$; volume, $30 \mathrm{ml})$ in the same buffer. The flow rate was $30 \mathrm{ml} / \mathrm{hr}$ and fractions of $0.7 \mathrm{ml}$ were collected. The active fractions, which were eluted at approximately $5 \%$ ammonium sulfate, were combined and then dialyzed against $10 \mathrm{~mm}$ Tris- $\mathrm{HCl}$ buffer $(\mathrm{pH} \mathrm{7.5)}$ at $4^{\circ} \mathrm{C}$ overnight. The dialysate was concentrated to about $2 \mathrm{ml}$ as above and then used for characterization of the glutathione synthetase.

Determination of the molecular weight. The molecular weight of the enzyme was determined by gel filtration on a calibrated column of Sephadex G-150 $(1.5 \times 95 \mathrm{~cm})$ equilibrated with $10 \mathrm{~mm}$ Tris- $\mathrm{HCl}$ buffer $(\mathrm{pH} 7.5)$, the proteins being eluted with the same buffer. Polyacrylamide gel electrophoresis in the presence or absence of sodium dodecyl sulfate was performed according to the method of Laemmli. ${ }^{17)}$

\section{Results and Discussion}

Glutathione synthetase was purified approximately 920 -fold from a cell extract of

Table I. Summary of the Purification of A. niger Glutathione Synthetase

\begin{tabular}{llcccc}
\hline Step & $\begin{array}{c}\text { Total } \\
\text { protein } \\
(\mathrm{mg})\end{array}$ & $\begin{array}{c}\text { Specific activity } \\
(\mu \mathrm{mol} / \mathrm{hr} / \mathrm{mg}- \\
\text { protein })\end{array}$ & $\begin{array}{c}\text { Total } \\
\text { activity } \\
(\mu \mathrm{mol} / \mathrm{hr})\end{array}$ & $\begin{array}{c}\text { Yield of } \\
\text { activity } \\
(\%)\end{array}$ & Fold \\
\hline 1. Cell extract & 4410 & 15.3 & 67470 & 100 & 1.0 \\
2. Ammonium sulfate & 1750 & 32.1 & 56180 & 83.3 & 2.1 \\
3. DEAE-cellulose & 195 & 278 & 54210 & 80.3 & 18.2 \\
4. 1st Sephadex G-150 & 52.8 & 990 & 52270 & 77.5 & 64.7 \\
5. DEAE-Sepharose CL-6B & 6.72 & 7140 & 47980 & 71.1 & 467 \\
6. 2nd Sephadex G-150 & 2.71 & 13200 & 35770 & 53.0 & 863 \\
7. Butyl-Toyopearl 650M & 1.33 & 14100 & 18750 & 27.8 & 962 \\
\hline
\end{tabular}

The purification procedures are described under Materials and Methods. The activity was determined by measuring the glutathione formed. 


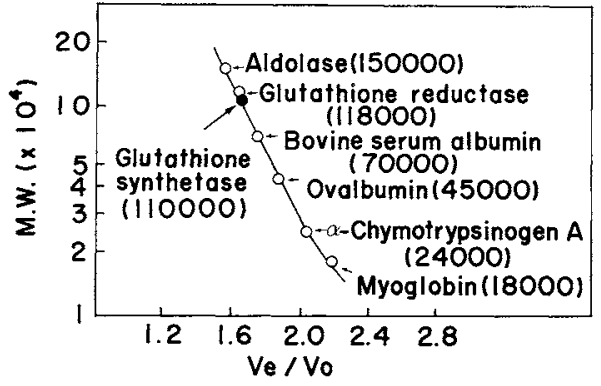

Fig. 1. Molecular Weight Determination of Glutathione Synthetase by Gel Filtration.

The Column conditions are given under Materials and Methods. $V e / V o$ was plotted as a function of molecular weight, where $V e$ is the elution volume of protein and $V o$ the void volume of the column. The elution position of the purified glutathione synthetase is indicated by a closed circle

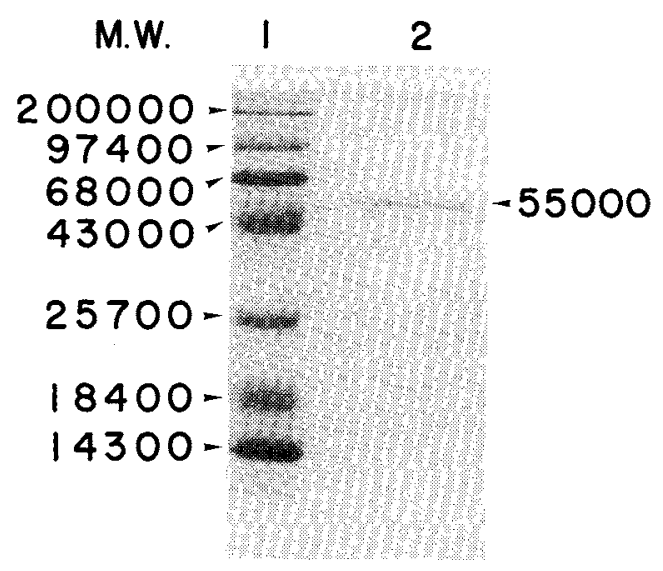

Fig. 2. Polyacrylamide Gel Electrophoresis of Glutathione Synthetase in the Presence of Sodium Dodecyl Sulfate.

Lane 1: standard proteins (from top; myosin (H-Chain), phosphorylase $b$, bovine serum albumin, ovalbumin, $\alpha$ chymotrypsinogen, $\beta$-lactoglobulin and lysozyme).

Lane 2: purified glutathione synthetase.

A. niger, with a $30 \%$ activity yield (Table I). The purified enzyme exhibited a single band on polyacrylamide gel electrophoresis in the absence of sodium dodecyl sulfate (data not shown). Determination of the molecular weight by gel filtration on a Sephadex G-150 column gave a value of 110,000 (Fig. 1). On the other hand, gel electrophoresis in the presence of sodium dodecyl sulfate indicated a

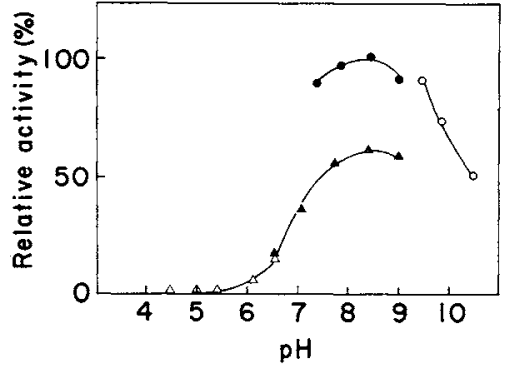

Fig. 3. Effect of $\mathrm{pH}$ on Glutathione Synthetase Activity. The reaction was carried out under the conditions given under Materials and Methods, except for the $\mathrm{pH}$ of the reaction mixture. Activities were determined by measuring the glutathione formed. $\triangle$, acetate buffer; $\boldsymbol{\Lambda}$, potassium phosphate buffer; - Tris- $\mathrm{HCl}$ buffer; $\mathrm{O}$, borate- $\mathrm{NaOH}$ buffer.

subunit molecular weight of 55,000 (Fig. 2), thus indicating that the mold glutathione synthetase consists of two apparently identical subunits. As explained under Introduction, the glutathione synthetase of the mold resembled that of mammals and yeast in molecular weight and structure [although the subunit structure of the yeast enzyme has not been reported $\left.{ }^{13)}\right]$, but was quite different from the bacterial enzymes.

The purified enzyme from $A$. niger exhibited a $\mathrm{pH}$ optimum in the range $8.0 \sim 8.5$ (Fig. 3). The apparent $K m$ values of the enzyme for $\gamma-\mathrm{L}-$ glutamyl-L-cysteine, glycine and ATP were calculated to be $0.8,1.3$ and $0.7 \mathrm{~mm}$, respectively, from Lineweaver-Burk plots. ${ }^{18)}$ The enzyme showed no detectable ATP-hydrolyzing activity in the presence or absence of the substrate ( $\gamma$-L-glutamyl-L-cysteine or glycine; data not shown). The enzyme was strictly specific to glycine. L-Amino acids (L-glutamate, L-glutamine, L-aspartate, L-asparagine, L-leucine, L-isoleucine, L-methionine, L-proline, L-tryptophan, L-threonine, L-arginine, Lhistidine, L-lysine, L-cysteine and L-tyrosine) were not utilized. The enzyme from the mold was almost completely specific to ATP. Other nucleotide triphosphates (CTP, GTP, ITP, TTP and UTP) could not substitute for ATP, although GTP gave barely detectable activity. In the absence of divalent cations, the mold 
Table II. EfFects of Various Chemicals on Glutathione Synthetase Activity

\begin{tabular}{lcc}
\hline Addition (mM) & & $\begin{array}{c}\text { Relative } \\
\text { activity } \\
(\%)\end{array}$ \\
\hline None & $(10)$ & 100 \\
Dithiothreitol & $(10)$ & 290 \\
Dithioerythritol & $(10)$ & 190 \\
2-Mercaptoethanol & $(10)$ & 65.5 \\
L-Cysteine & $(5.0)$ & 51.3 \\
Iodoacetamide & $(5.0)$ & 67.8 \\
Acetamide & $(5.0)$ & 50.5 \\
$N$-Ethylmaleimide & $(0.1)$ & 0 \\
$p$-Chloromercuribenzoate & $(1.0)$ & 0 \\
HgCl & $(1.0)$ & 85.1 \\
Glutathione (reduced) & $(5.0)$ & 70.4 \\
& $(10)$ & 59.7 \\
& $(1.0)$ & 97.6 \\
Glutathione (oxidized) & $(5.0)$ & 93.7 \\
& $(10)$ & 90.9
\end{tabular}

The reactions were carried out under the conditions given under Materials and Methods, except that the various chemicals were added. Activities were determined by measuring inorganic phosphate formed. The activity with no addition was taken as $100 \%$

enzyme showed no activity. $\mathrm{Mg}^{2+}$ and $\mathrm{Mn}^{2+}$ were preferentially required for the catalytic function, with almost the same efficiencies. Other metal ions $\left(\mathrm{Co}^{2+}, \mathrm{Cu}^{2+}, \mathrm{Ni}^{2+}, \mathrm{Ba}^{2+}\right.$, $\mathrm{Ca}^{2+}, \mathrm{Fe}^{2+}, \mathrm{Sr}^{2+}$ and $\left.\mathrm{Li}^{2+}\right)$ showed no appreciable effects on the enzyme activity. The potassium ion did not activate the mold enzyme, though the ion is required for the maximum activity of the glutathione synthetase from rat kidney ${ }^{12)}$ and yeast. ${ }^{19)}$ In analogy with the case of the enzymes from rat kidney, ${ }^{12)} P$. mirabilis ${ }^{11)}$ and $E$. coli $B,{ }^{10)}$ the activity of the mold enzyme was completely inhibited by $1.0 \mathrm{~mm} \mathrm{HgCl}_{2}$ or $0.1 \mathrm{~mm}$ p-chloromercuribenzoate (Table II), thus suggesting that it also contains an active site thiol. On the other hand, reducing agents activated the mold enzyme, two- to three-fold increases in activity being observed in the presence of $10 \mathrm{~mm}$ dithiothreitol, dithioerythritol or 2-mercaptoethanol (Table II). Similar results have been reported in the case of the enzyme from $P$. mirabilis. ${ }^{11}$ The activity of glutathione syn- thetase from $E$. coli $B$ is feedback-inhibited by the oxidized form of glutathione, but not by the reduced form, ${ }^{10}$ ) the inhibition being more than $90 \%$ in the presence of $10 \mathrm{~mm}$ oxidized glutathione. However, the mold enzyme was rather insensitive to both types of glutathione, the inhibition being $40 \%$ and $10 \%$ in the presence of $10 \mathrm{~mm}$ of the reduced and oxidized forms of glutathione, respectively (Table II).

Thus, the results obtained indicate that the molecular structure of glutathione synthetase is quite different between eukaryotes and prokaryotes, although the enzymes from both types of organisms contain an active site thiol and catalyze the same reaction. The glutathione synthetases of eukaryotes (mold, yeast and rat kidney) have molecular weights in the range $110,000 \sim 120,000$ and consist of two apparently identical subunits. On the other hand, the enzyme of prokaryotes $(E$. coli $B$ and $P$. mirabilis) have molecular weights of about 150,000 and the $E$. coli $B$ enzyme consists of four identical subunits. Comparison of the base sequences of the genes for glutathione synthetases of mammals, mold (or yeast) and bacterial cells would be important for elucidation of the evolution of glutathione synthetase.

\section{References}

1) J. E. Snoke, S. Yanari and K. Bloch, J. Biol. Chem., 201, 573 (1985).

2) R. B. Johnson and K. Bloch, J. Biol. Chem., 188, 221 (1951).

3) P. W. Majerans, M. J. Brauner, M. B. Smith and V. J. Minnich, J. Clin. Invest., 50, 1637 (1971).

4) A. Wendell, E. Schaich, U. Webwe and L. Floche, Hoppe-Seyler's Z. Physiol. Chem., 353, 514 (1972).

5) L. L. Ross, L. Barber, S. S. Tate and A. Meister, Proc. Natl. Acad. Sci. U.S.A., 70, 2211 (1973).

6) G. C. Webster and J. E. Varer, Arch. Biochem. Biophys., 55, 95 (1955).

7) J. E. Snoke, J. Biol. Chem., 213, 813 (1955).

8) J. S. Nishimura, E. A. Dodd and A. Meister, J. Biol. Chem., 239, 2553 (1964).

9) P. J. Samuels, Biochem. J., 55, 441 (1953).

10) H. Gushima, T. Miya, K. Murata and A. Kimura, $J$. Appl. Biochem., 5, 210 (1983).

11) R. Nakayama, Studies on Glutathione Metabolising 
Enzymes in Bacteria (Ph. D. Thesis, Kyoto University, 1984), pp. $58 \sim 62$.

12) L. Oppenheimer, V. P. Wellner, O. W. Griffith and A. Meister, J. Biol. Chem., 254, 5184 (1979).

13) A. Meister, in "The Enzyme," Vol. 10, ed. by P. D. Boyer, Academic Press, New York, 1974, p. 671.

14) F. Tietze, Anal. Biochem., 27, 502 (1969).

15) C. H. Fiske and Y. Subbarow, J. Biol. Chem., 65, 375
(1946).

16) O. H. Lowry, N. J. Rosebrough, A. L. Farr and R. J. Randall, J. Biol. Chem., 193, 265 (1951).

17) U. K. Laemmli, Nature (London), 227, 650 (1974).

18) H. Lineweaver and D. Burk, J. Am. Chem. Soc., 56, 658 (1934).

19) E. D. Mooz and A. Meister, Biochemistry, 6, 1722 (1967). 